\title{
Bioenergetic Properties of Alkaline-tolerant and Alkalophilic Strains of Bacillus firmus
}

\author{
By ARTHUR A. GUFFANTI, ROBERT BLANCO, ROBERT A. BENENSON \\ AND TERRY A. KRULWICH* \\ Department of Biochemistry, Mount Sinai School of Medicine of the City University of New \\ York, New York, New York 10029, U.S.A.
}

(Received 3 October 1979; revised 4 January 1980)

\begin{abstract}
The protonmotive force, $\mathrm{Na}^{+} / \mathrm{H}^{+}$antiport activity and $\alpha$-aminoisobutyric acid transport were studied in alkaline-tolerant Bacillus firmus ATCC 14575 and in a newly isolated alkalophilic strain of the same species. The alkalophilic strain, which grew over a $\mathrm{pH}$ range from 8.0 to 10.5 , maintained a cytoplasmic $\mathrm{pH}$ of 9.5 or below even at an external $\mathrm{pH}$ of 11.0. Evidence was obtained for an electrogenic $\mathrm{Na}^{+} / \mathrm{H}^{+}$antiporter which could play a role in acidification of the cytoplasm as well as in generation of the transmembrane electrical potential. A non-alkalophilic strain, isolated after mutagenesis of the new alkalophile, lacked the $\mathrm{Na}^{+} / \mathrm{H}^{+}$antiporter. The alkaline-tolerant strain of $B$. firmus, which grew at $\mathrm{pH}$ values between 6.5 and 8.5 , did not maintain an acidified cytoplasm as the $\mathrm{pH}$ was raised above $8 \cdot 0$. A less active, apparently electroneutral, $\mathrm{Na}^{+} / \mathrm{H}^{+}$exchange was found in this strain. Both the alkaline-tolerant and alkalophilic strains exhibited $\mathrm{Na}^{+}$-dependent transport of $\alpha$-aminoisobutyric acid.
\end{abstract}

\section{INTRODUCTION}

The special bioenergetic problems posed by life at alkaline $\mathrm{pH}$, especially the generation of the protonmotive force (p.m.f.) and its involvement in solute transport, have been studied in one alkaline-tolerant (Guffanti et al., 1979b) and one alkalophilic species of Bacillus (Guffanti et al., 1978, 1979a). The former, a Bacillus circulans strain, could grow at pH values between 6.5 and 9.5 , while the latter, Bacillus alcalophilus, could only grow at alkaline $\mathrm{pH}$ values, from 8.0 to $11 \cdot 5$. The studies suggested that the upper limit of cytoplasmic $\mathrm{pH}$ that is compatible with viability is 9.0 to 9.5 , which corresponds to the upper pH limit for growth of alkaline-tolerant organisms (Guffanti et al., 1979b). The true alkalophile maintains a cytoplasmic $\mathrm{pH}$ of 9.0 to 9.5 as the $\mathrm{pH}$ is raised further, thus growing optimally under conditions in which the cytoplasm is more acidic than the external milieu (Guffanti et al., 1978). In membrane vesicles this reversed $\Delta \mathrm{pH}$ could only be generated in the presence of $\mathrm{Na}^{+}$; work with vesicles and starved intact cells indicated that an electrogenic $\mathrm{Na}^{+} / \mathrm{H}^{+}$ antiporter is critically involved in the maintenance of an acidified cytoplasm (Mandel \& Krulwich, 1979).

The p.m.f., the sum of the reversed $\Delta \mathrm{pH}$ and the transmembrane electrical potential or $\Delta \psi$ (Mitchell, 1961), is very small in B. alcalophilus. The alkalophile must be able to energize transport, ATP synthesis, etc. using this small p.m.f. or some alternative mechanism. In previous studies, we found that $\alpha$-aminoisobutyric acid (AIB) transport occurs in symport with $\mathrm{Na}^{+}$, energized by the $\Delta \psi$ (Guffanti et al., 1978), and that $\beta$-galactosides are transported by an ATP-dependent mechanism (Guffanti et al., 1979a). The mechanism of ATP synthesis in this species is currently under investigation in our laboratory.

Recently, we isolated a new alkalophilic strain of Bacillus in order to verify that the 
bioenergetic patterns of $B$. alcalophilus are not some special property of that species. The new isolate was identified as an obligately alkalophilic strain of Bacillus firmus, a species that is typically alkaline-tolerant. Thus, it has been possible to compare directly alkalinetolerant and truly alkalophilic strains of the same species. We have further been able to isolate a non-alkalophilic mutant of the new isolate. The findings of the previous studies have been extended to include evidence for the existence of an electrogenic $\mathrm{Na}^{+} / \mathrm{H}^{+}$antiporter whose activity is correlated with the ability to grow at highly alkaline $\mathrm{pH}$.

\section{METHODS}

Bacteria and growth conditions. Bacillus firmus ATCC 14575 was obtained from the American Type Culture Collection. A bacterium able to grow at $\mathrm{pH} 10.5$ was isolated from garden soil by enrichment culture techniques, using alkaline medium containing L-malate as the carbon source, and was purified by single colony isolation from solid medium. On the basis of its morphological and physiological characteristics, the isolate has been identified by Dr Ruth Gordon (Waksman Institute of Microbiology, Rutgers University, New Brunswick, N.J., U.S.A.) as an alkalophilic strain of B. firmus. Several similar strains have recently been characterized by Gordon (1980). Bacillus firmus 14575 is a moderately alkaline-tolerant strain which grows at $\mathrm{pH}$ values between 6.5 and 8.5. The alkalophilic strain (B. firmus $\mathrm{RAB}$ ) grows well between $\mathrm{pH} 8.0$ and 10.5 . The basal growth medium for $B$. firmus RAB was that described previously for $B$. alcalophilus (Guffanti et al., 1978), adjusted to $\mathrm{pH} 10 \cdot 5$. Bacillus firmus 14575 was grown on a basal medium containing Tris and phosphate buffers (Guffanti et al., 1979 b) adjusted to $\mathrm{pH} 7 \cdot 5$. The carbon source for both organisms was $50 \mathrm{mM}-\mathrm{L}$-malate, supplemented with $0.1 \%(\mathrm{w} / \mathrm{v})$ yeast extract, $0.2 \%(\mathrm{w} / \mathrm{v})$ peptone and $1 \%(\mathrm{v} / \mathrm{v})$ trace salts solution (Hegeman, 1966). Both organisms were grown at $30{ }^{\circ} \mathrm{C}$ with shaking at $200 \mathrm{rev} . \mathrm{min}^{-1}$ in a New Brunswick G25, rotary shaker. Growth was followed turbidimetrically with a Klett-Summerson colorimeter (no. 42 filter).

A non-alkalophilic mutant of $B$. firmus RAB was isolated after mutagenesis with ethyl methanesulphonate, as described previously (Wolfson \& Krulwich, 1972), and plating on L-malate-containing medium buffered to pH 5.5 with potassium phosphate. Organisms grown from a single colony on such plates were designated as B. firmus RABN; this mutant grew on L-malate-containing medium only over a range of external $\mathrm{pH}$ from 5.5 to $8 \cdot 5$.

Chemicals. Lysozyme (EC 3.2.1.17) (egg white), gramicidin, luciferin-firefly tails and $N, N, N^{\prime}, N^{\prime}$-tetramethyl- $p$-phenylenediamine (TMPD) were from Sigma. $\left[{ }^{14} \mathrm{C}\right] \mathrm{Inulin}\left(270 \mathrm{Ci} \mathrm{g}^{-1}, 10 \mathrm{TBq} \mathrm{g}^{-1}\right),{ }^{3} \mathrm{H}_{2} \mathrm{O}(250 \mu \mathrm{Ci}$ $\left.\mathrm{ml}^{-1}, 9.3 \mathrm{MBq} \mathrm{ml}{ }^{-1}\right),\left[{ }^{14} \mathrm{C}\right]$ methylamine hydrochloride $\left(52.2 \mathrm{mCi} \mathrm{mmol}^{-1}, 1.93 \mathrm{GBq} \mathrm{mmol}{ }^{-1}\right), 5,5-\left[2-{ }^{14} \mathrm{C}\right]-$ dimethyloxazolidine-2,4-dione (DMO) $\left(8.8 \mathrm{mCi} \mathrm{mmol}^{-1}, 326 \mathrm{MBq} \mathrm{mmol}^{-1}\right),{ }^{22} \mathrm{NaCl}\left(10 \mathrm{mCi} \mathrm{mmol}{ }^{-1}, 370\right.$ MBq mmol $\left.{ }^{-1}\right), \alpha-\left[1-^{14} \mathrm{C}\right] \mathrm{AIB}\left(9 \cdot 0 \mathrm{mCi} \mathrm{mmol}{ }^{-1}, 333 \mathrm{MBq} \mathrm{mmol}{ }^{-1}\right)$ and $\left.{ }^{3} \mathrm{H}\right]$ triphenylmethylphosphonium bromide $\left(\mathrm{TPMP}^{+}\right)\left(18.3 \mathrm{mCi} \mathrm{mmol}^{-1}, 677 \mathrm{MBq} \mathrm{mmol}^{-1}\right)$ were from New England Nuclear. Non-radioactive $\mathrm{TPMP}^{+}$was purchased from ICN-K\&K Laboratories.

Assays. Transport of AIB was measured by filtration as described previously (Guffanti et al., 1978), except that $500 \mu \mathrm{M}-\left[{ }^{14} \mathrm{C}\right] \mathrm{AIB}\left(1 \mu \mathrm{Ci} \mu \mathrm{mol}^{-1}, 37 \mathrm{kBq} \mu \mathrm{mol}^{-1}\right)$ was used. The transmembrane $\Delta \mathrm{pH}$ was measured by the distribution of $\left[{ }^{14} \mathrm{C}\right]$ methylamine or $\left[{ }^{14} \mathrm{C}\right] \mathrm{DMO}$, in a flow dialysis assay modified according to Ramos et al. (1976). The transmembrane electrical potential was determined in a filtration assay (Schuldiner \& Kaback, 1975) by measuring the accumulation of $\left.{ }^{3} \mathrm{H}\right] \mathrm{TPMP}{ }^{+}$. The total p.m.f. $\left(\Delta \bar{\mu}_{\mathrm{B}}+\right)$ was calculated from the equation $\Delta \bar{\mu}_{\mathrm{H}^{+}}=\Delta \psi-\mathrm{Z} \Delta \mathrm{pH}$, where $\mathrm{Z}=58.8 \mathrm{mV}$ at $25^{\circ} \mathrm{C}$. Care was taken to include the controls described previously (Guffanti et al., 1978) for measurements of $\Delta \psi, \Delta \mathrm{pH}$ and AIB uptake. The intracellular water volume, as determined by the method of Stock et al. (1977), was 10.2 and $10.8 \mu \mathrm{l} \mathrm{cell} \mathrm{H}_{2} \mathrm{O}$ (mg cell protein $)^{-1}$ for $B$. firmus strains 14575 and RAB, respectively. Cellular ATP was measured with the luciferinluciferase assay (Stanley \& Williams, 1969) in organisms extracted with perchloric acid (Cole et al., 1967) as described elsewhere (Guffanti et al., 1978). Protein was determined by the method of Lowry, using egg-white lysozyme as the standard.

The efflux of ${ }^{22} \mathrm{Na}^{+}$was measured with starved organisms by a variation of the method of Schuldiner \& Fishkes (1978). Organisms were washed and suspended in 25 mM-potassium carbonate buffer, pH 10.5, or $25 \mathrm{~mm}$-potassium phosphate buffer, $\mathrm{pH} 8.0$, at $1 \mathrm{mg}$ protein $\mathrm{ml}^{-1}$ and starved for 3 to $5 \mathrm{~h}$ by shaking at $200 \mathrm{rev}$. $\mathrm{min}^{-1}$ at $30^{\circ} \mathrm{C}$. The starved organisms were loaded with $1 \mathrm{~mm}^{-22} \mathrm{NaCl}$ at $4{ }^{\circ} \mathrm{C}$ for $1 \mathrm{~h}$. Portions were removed and transferred to reaction vessels at $25^{\circ} \mathrm{C}$ to which the appropriate additions were made. Samples $(200 \mu \mathrm{l})$ were removed, filtered and washed rapidly with $25 \mathrm{~mm}$-potassium carbonate buffer, $\mathrm{pH} 10.5$ or potassium phosphate, pH 8.0. Filtration and washing were completed within 5 to $10 \mathrm{~s}$. Slower rates of filtration led to considerable ${ }^{22} \mathrm{Na}^{+}$leakage.

Tracings of the external pH were conducted as described by Niven \& MacLeod (1978). Organisms were suspended at 5 to $10 \mathrm{mg}$ protein $\mathrm{ml}^{-1}$ and starved in a reaction mixture of $300 \mathrm{~mm}$-choline chloride, $50 \mathrm{mM}$ - 
$\mathrm{MgSO}_{4}, 1 \mathrm{mM}$-Tris/ $\mathrm{HCl}$, and $20 \mu \mathrm{g}$ carbonic anhydrase $\mathrm{ml}^{-1}$. The suspension was kept anaerobic by bubbling with oxygen-free nitrogen, and the $\mathrm{pH}$ was adjusted with anaerobic solutions of $\mathrm{HCl}$ or choline hydroxide. The pH was measured with a Beckman Expandomatic pH meter (combination pH electrode 39012) connected to a strip chart recorder with full-scale deflection set at $0.2 \mathrm{pH}$ unit. Additions of either $10 \mathrm{~mm}-$ $\mathrm{NaCl}$ or $10 \mathrm{~mm}-\mathrm{KCl}$ were made from anaerobic solutions.

\section{RESULTS}

The $\Delta \mathrm{pH}$ and $\Delta \psi$ were determined, and the cytoplasmic $\mathrm{pH}$ and p.m.f. $\left(\Delta \bar{\mu}_{\mathrm{B}^{+}}\right)$were calculated for each $B$. firmus strain over a range of external $\mathrm{pH}$ values. Bacillus firmus 14575 maintained a cytoplasmic $\mathrm{pH}$ of approximately 8.0 over an external $\mathrm{pH}$ range from 6.5 to 8.0 (Fig. 1). Thus in this $\mathrm{pH}$ range, a $\Delta \mathrm{pH}$, outside acid, was generated. At higher external $\mathrm{pH}$ values, the $\Delta \mathrm{pH}$ was zero. The $\Delta \psi^{\prime}$ increased from $-77 \mathrm{mV}$ at $\mathrm{pH} 6.5$ to $-137 \mathrm{mV}$ at $\mathrm{pH} 9.0$ and then began to decline. By contrast, $B$. firmus $\mathrm{RAB}$ maintained a cytoplasmic $\mathrm{pH}$ of 9.5 or less over a range of external $\mathrm{pH}$ values from 8.0 to 11.0 ; the $\Delta \psi$ increased over that entire range from -89 to $-145 \mathrm{mV}$ (Fig. 2). The p.m.f. of the alkaline-tolerant strain was highest at neutral or slightlyacidic external $\mathrm{pH}$ values; that of the alkalophile was highest at $\mathrm{pH} 9 \cdot 5$, the most alkaline $\mathrm{pH}$ at which a reversed $\Delta \mathrm{pH}$ was not produced.

The possible existence of monovalent cation $/ \mathrm{H}^{+}$antiporters was then examined. At alkaline $\mathrm{pH}$, such antiporters might be involved in the maintenance of the $\Delta \psi$ in $B$. firmus 14575 and of both the $\Delta \psi$ and reversed $\Delta \mathrm{pH}$ in $B$. firmus RAB. First, suspensions of the organisms in lightly buffered medium at $\mathrm{pH} 8.0$ or 10.5 were exposed to a sudden addition of $\mathrm{NaCl}$ or $\mathrm{KCl}$ to a final concentration of $10 \mathrm{~mm}$. The conditions used were those described by Niven \& MacLeod (1978). Suspensions of both strains at $\mathrm{pH} 8.0$ and at $\mathrm{pH} 10.5$ showed a slight acidification of the medium (approximately $0.01 \mathrm{pH}$ units) upon addition of $\mathrm{NaCl}$. No change was observed upon addition of $\mathrm{KCl}$. Efflux of $\mathrm{Na}^{+}$from starved organisms which had been loaded with ${ }^{22} \mathrm{Na}^{+}$was then studied (Fig. 3). At $\mathrm{pH} 10.5$ neither strain showed efflux of $\mathrm{Na}^{+}$in the absence of energization. Upon addition of ascorbate/TMPD, ${ }^{22} \mathrm{Na}^{+}$effluxed rapidly from $B$. firmus RAB (Fig. $3 a$ ). The efflux was markedly reduced by the lipophilic cation TPMP+, which was used to dissipate the $\Delta \psi$ without itself making the membrane permeable to $\mathrm{Na}^{+}$. Bacillus firmus 14575 exhibited a much slower, TPMP+-insensitive, efflux of ${ }^{22} \mathrm{Na}^{+}$upon energization (Fig. $3 b$ ). Parallel measurements under the same conditions indicated that equivalent $\Delta \psi$ values, in the range -80 to $-90 \mathrm{mV}$, were generated in the two strains upon addition of ascorbate/TMPD to the starved organisms. The relative ${ }^{22} \mathrm{Na}^{+}$efflux exhibited by the two $B$. firmus strains was essentially the same at $\mathrm{pH} 8.0$ as at $\mathrm{pH} 10 \cdot 5$ (Table 1). Moreover, use of valinomycin to cause dissipation of the $\Delta \psi$ resulted in levels of inhibition in $B$. firmus RAB similar to those observed with TPMP ${ }^{+}$. Valinomycin did not inhibit the more modest ${ }^{22} \mathrm{Na}^{+}$efflux found in $B$. firmus 14575 . However, carbonyl cyanide $m$-chlorophenylhydrazone (CCCP) [used at concentrations shown previously to cause transmembrane proton movement at alkaline $\mathrm{pH}$ (Guffanti et al., 1978)] inhibited ${ }^{22} \mathrm{Na}^{+}$efflux in this strain.

The non-alkalophilic mutant $B$. firmus RABN had been isolated because of the possibility that if a specific cation/proton antiporter facilitates growth at high $\mathrm{pH}$ by maintaining an acidified cytoplasm, then activity of that same antiporter might preclude growth of the alkalophile at neutral $\mathrm{pH}$ by causing acidification beyond some critical buffering capacity of the cytoplasm. A non-alkalophilic mutant might thus be expected to lack the relevant antiporter. The mutant exhibited no ${ }^{22} \mathrm{Na}^{+}$efflux at either $\mathrm{pH} 8.0$ or 10.5 under the conditions employed for the other two strains (Table 1). Moreover, addition of $\mathrm{NaCl}$ to suspensions of mutant RABN in lightly buffered medium failed to cause the slight acidification observed under the same conditions with $B$. firmus 14575 and $B$. firmus RAB (results not shown).

The final bioenergetic property studied in $B$. firmus 14575 and $B$. firmus RAB was an active transport system for AIB. Uptake of AIB occurred optimally at $\mathrm{pH} 7.5$ in $B$. firmus 14575 and at $\mathrm{pH} 9.0$ in $B$. firmus RAB. The AIB accumulated could be shown by extraction 


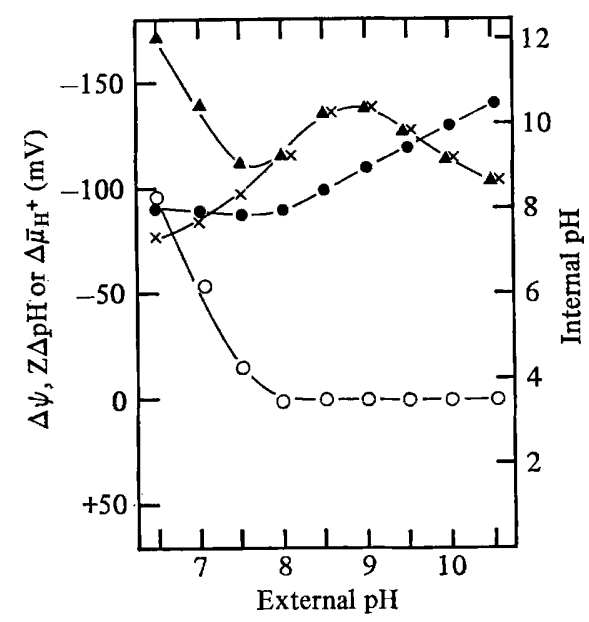

Fig. 1

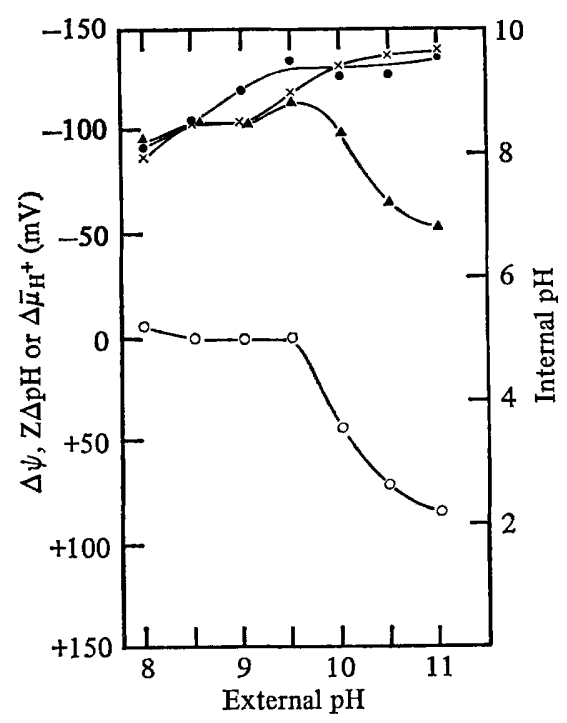

Fig. 2

Fig. 1. Effect of external pH on internal pH (O), $\Delta \psi(x), \mathrm{Z} \Delta \mathrm{pH}(0)$ and $\Delta \vec{\mu}_{\mathrm{H}^{+}}(\boldsymbol{\Delta})$ in $B$. firmus 14575. Organisms grown at $\mathrm{pH} 7.5$ were washed and suspended in either $25 \mathrm{~mm}-\mathrm{Na}_{2} \mathrm{CO}_{3} / \mathrm{NaHCO}_{3}$ buffer (pH 9.0 to 11.0 ) or 25 mM-Tris/25 mm-sodium phosphate (pH 6.5 to 9.5). Measurements were made as described in Methods. All points are the average of at least two determinations.

Fig. 2. Effect of external pH on internal pH (O), $\Delta \psi(\times), \mathrm{Z} \Delta \mathrm{pH}(0)$ and $\Delta \bar{\mu}_{\mathrm{H}}+(\boldsymbol{\Delta})$ in $B$. firmus RAB. Measurements were made as described in Methods and in the legend to Fig. 1.

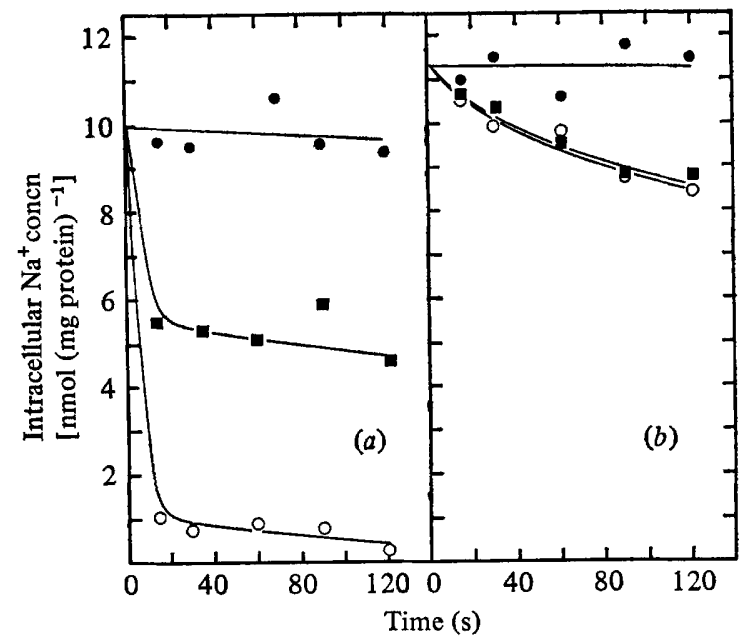

Fig. 3. Effect of an energy source and an inhibitor of $\Delta \psi$ on $\mathrm{Na}^{+}$extrusion in starved $B$. firmus $\mathrm{RAB}(a)$ and $B$. firmus $14575(b)$. Organisms were starved at $\mathrm{pH} 10.5$ as described in Methods and loaded with $1 \mathrm{~mm}^{22} \mathrm{NaCl}$. Samples were taken, rapidly filtered and washed with $25 \mathrm{~mm}$-potassium carbonate buffer, pH 10.5. No additions were made to control suspensions (O), while $20 \mathrm{~mm}$ potassium ascorbate plus $2 \mathrm{~mm}$-TMPD were added to other suspensions in the presence ( $\square$ ) or absence $(O)$ of $1 \mathrm{mM}-\mathrm{TPMP}+$. 


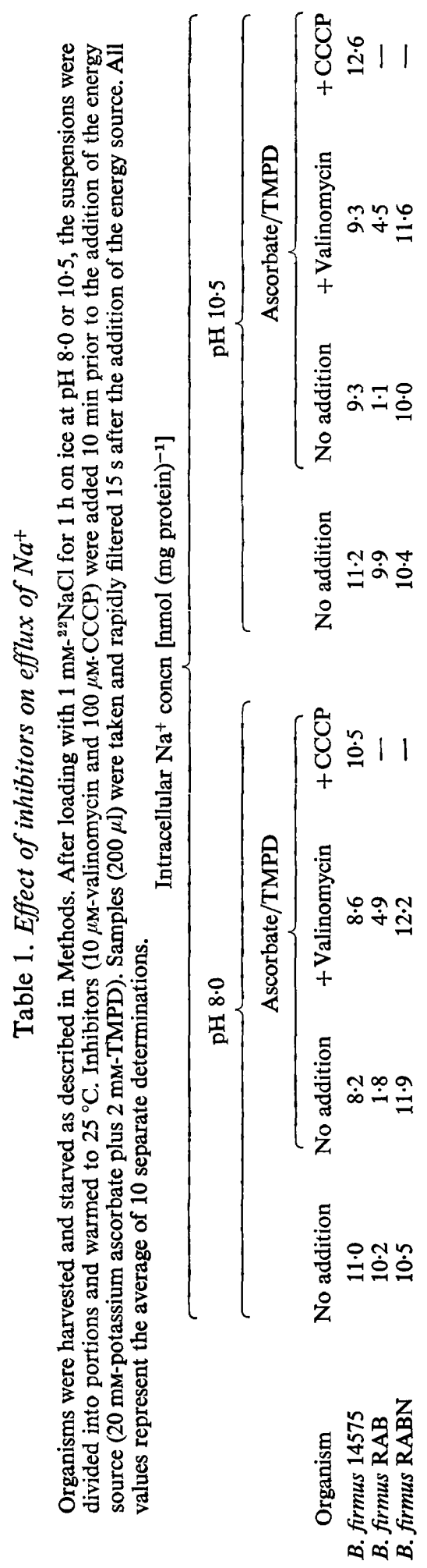




\section{Table 2. Effect of various ions on AIB uptake}

Organisms were grown on L-malate, washed and suspended in $25 \mathrm{mM}$-Tris/HCl, pH 9.0 (B. firmus $\mathrm{RAB}$ ) or pH 7.5 (B. firmus 14575). The various salts were added to a final concentration of $10 \mathrm{~mm}$.

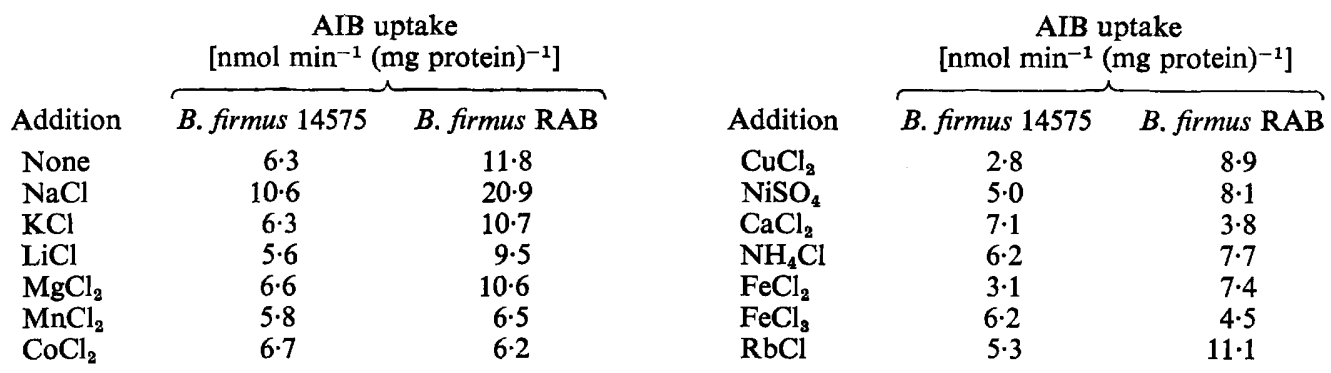

(Thompson, 1976) and chromatography (Pillay \& Mehdi, 1970) to be identical to authentic AIB. Concentrative uptake of the solute was dependent on the presence of $\mathrm{Na}^{+}$in both strains. This dependence was particularly clear when steady-state levels of accumulation were examined after $1 \mathrm{~h}$ of uptake. In the absence of $\mathrm{Na}^{+}, B$. firmus 14575 and $B$. firmus $\mathrm{RAB}$ accumulated AIB to 8.5 and $19.0 \mathrm{nmol} \mathrm{h}^{-1}$ (mg protein) ${ }^{-1}$, respectively. In the presence of $\mathrm{Na}^{+}(10 \mathrm{mM}), B$. firmus 14575 and $B$. firmus RAB accumulated AIB to 119.9 and 419.4 $\mathrm{nmol} \mathrm{h} \mathrm{h}^{-1}$ (mg protein) $)^{-1}$, respectively. Other cations failed to stimulate the initial rate of AIB uptake (Table 2). In the presence of $\mathrm{Na}^{+}$, AIB uptake exhibited Michaelis-Menten kinetics with a $K_{\mathrm{m}}$ of $260 \mu \mathrm{M}$ in B. firmus 14575 and $320 \mu \mathrm{M}$ in B. firmus RAB. The AIB transport system was examined in greater detail in the alkalophilic strain. Gramicidin, an agent that dissipated the $\Delta \psi$, completely inhibited AIB transport (results not shown). By contrast, a direct involvement of ATP in the AIB transport system was not found. Bacillus firmus $\mathrm{RAB}$ was incubated in medium containing $10 \mathrm{mM}$-sodium arsenate for $30 \mathrm{~min}$ at $30{ }^{\circ} \mathrm{C}$. After washing, the treated and control organisms were assayed for cellular ATP content and AIB transport. Arsenate treatment lowered the ATP content from 3.35 to 0.33 nmol ATP (mg cell protein) ${ }^{-1}$, while AIB transport was completely unaffected.

\section{DISCUSSION}

The major findings of previous studies on the p.m.f. generated by alkaline-tolerant and alkalophilic organisms have been confirmed. Again, growth of the two strains examined here occurred only at external $\mathrm{pH}$ values at which the cytoplasmic $\mathrm{pH}$ could be maintained at 9.5 or below. While both the alkaline-tolerant and alkalophilic strains exhibited substantial $\Delta \psi$ values above $\mathrm{pH} 9 \cdot 5$, only the alkalophilic strain maintained a reversed $\Delta \mathrm{pH}$.

We had proposed previously that one of the important differences between alkalinetolerant and alkalophilic bacilli might be in the property of a cation/proton antiporter (Guffanti et al., 1979b); subsequent investigations of an alkalophile indeed indicated a role for a $\mathrm{Na}^{+} / \mathrm{H}^{+}$antiporter in acidification of the cytoplasm (or intravesicular space) of $B$. alcalophilus (Mandel \& Krulwich, 1979). An electrogenic $\mathrm{Na}^{+} / \mathrm{H}^{+}$antiporter could function to maintain an acidified cytoplasm as long as its activity returned more protons to the cytoplasm (or intravesicular space) than were being extruded by respiration. As a hypothetical example: suppose two protons were extruded during respiration and the antiporter, equally rapidly, exchanged three protons for two intracytoplasmic $\mathrm{Na}^{+}$ions. The antiporter activity alone $\left(2 \mathrm{Na}^{+}\right.$extruded $/ 3 \mathrm{H}^{+}$taken up) would be electrogenic in the direction that would allow its energization by the $\Delta \psi$, and/or a gradient of $\mathrm{Na}^{+}$, where $\mathrm{Na}^{+}{ }_{1 n}>\mathrm{Na}^{+}{ }_{\text {out }}$, augmented by the transient gradient of protons produced by respiration. The total movement of ions that would result from respiration and the antiporter, in the example, would produce an acidified cytoplasm and a $\Delta \psi$, outside positive. 
Does a $\mathrm{Na}^{+} / \mathrm{H}^{+}$antiporter function to acidify the cytoplasm in $B$. firmus $\mathrm{RAB}$, and could the difference between the alkaline-tolerant and alkalophilic strains relate to differences in the antiporters? Indeed, the alkalophilic strain appears to possess a $\Delta \psi$-dependent antiporter as indicated by: (i) $\mathrm{Na}^{+}$-induced proton efflux from cells and (ii) energy-dependent $\mathrm{Na}^{+}$efflux that was partially sensitive to TPMP+ or valinomycin (in the presence of $\mathrm{K}^{+}$). That this antiporter activity is actually involved in maintenance of the acidified cytoplasm is strongly indicated by the observation that a non-alkalophilic mutant lacks the activity. By contrast, the naturally alkaline-tolerant strain $B$. firmus 14575 appears to possess a less active antiporter than $B$. firmus $\mathrm{RAB}$. The $\mathrm{Na}^{+} / \mathrm{H}^{+}$antiporter in $B$. firmus 14575 catalyses an energy-dependent, $\Delta \psi$-independent $\mathrm{Na}^{+}$efflux, as indicated by its insensitivity to TPMP ${ }^{+}$ or valinomycin. This antiporter may be energized by the transient chemical gradient resulting from primary proton extrusion, since it was completely inhibited by CCCP. Thus, the $\mathrm{Na}^{+} /$ $\mathrm{H}^{+}$antiporter of $B$. firmus 14575 could not produce an acidified cytoplasm, in contrast to that of the alkalophile.

While these considerations all indicate that $\mathrm{Na}^{+} / \mathrm{H}^{+}$antiporters with different properties correlate with the relative ability to grow at alkaline $\mathrm{pH}$, a much more clear cut demonstration of $\mathrm{Na}^{+}$-dependent proton movements should be obtained in both strains. Such a demonstration will strengthen the inference that the inhibitor-sensitive $\mathrm{Na}^{+}$movements indicate $\mathrm{Na}^{+} / \mathrm{H}^{+}$antiporter activity. In future studies, we intend to use membrane vesicles of known orientation, together with techniques that will facilitate monitoring of proton fluxes.

There are reports of electrogenic cation/proton antiporters in Escherichia coli (Schuldiner \& Fishkes, 1978; Brey \& Rosen, 1979) and Halobacterium halobium (Lanyi \& MacDonald, 1976); similar antiporters described in other species of bacteria (Bhattacharyya \& Barnes, 1978; Harold \& Papineau, 1972; Niven \& MacLeod, 1978) may also be electrogenic. A role for antiporters in the conversion of the $\Delta \mathrm{pH}$, produced by primary proton extrusion to a $\Delta \psi$, with $\Delta \mathrm{pH}=0$, had been suggested previously in connection with studies of the p.m.f. in vesicles (Ramos \& Kaback, 1977). A specific involvement of a $\mathrm{Na}^{+} / \mathrm{H}^{+}$antiporter (Padan et al., 1976; Schulachev, 1978; Schuldiner \& Fishkes, 1978) and of the $\mathbf{K}^{+} / \mathbf{H}^{+}$antiporter (Brey \& Rosen, 1979) in the maintenance of cytoplasmic $\mathrm{pH}$ have been proposed in E. coli. The alkalophiles seem to offer an extreme biological situation in which the roles of the antiporters can be readily examined.

We are indebted to Dr Ruth Gordon for identifying the newly isolated alkalophile as a strain of Bacillus firmus. This work was supported in part by research grants PCM 7725586 and PCM 7810213 from the National Science Foundation. Dr Krulwich is the recipient of Research Career Development Award 5K04 GM00020 from the National Institutes of Health.

\section{REFERENCES}

Bhattacharyya, P. \& Barnes, E. M., JR (1978). Proton-coupled sodium uptake by membrane vesicles from Azotobacter vinelandii. Journal of Biological Chemistry 253, 3848-3851.

BRey, R. N. \& Rosen, B. P. (1979). Cation/proton antiport systems in Escherichia coli. Journal of Biological Chemistry 254, 1957-1963.

Cole, J., Wimpenny, J. W. T. \& Hughes, D. E. (1967). The ATP pool in Escherichia coli. I. Measurement of the pool using a modified luciferase assay. Biochimica et biophysica acta 143, 445-453.

GoRDON, R. E. (1980). 107 years of the genus Bacillus. In The Aerobic Endospore-forming Bacteria: Classification and Identification (in the
Press). Edited by R. C. W. Berkeley \& M. Goodfellow. London: Academic Press.

Guffanti, A. A., Susman, P., Blanco, R. \& KrulWICH, T. A. (1978). The protonmotive force and $\alpha$-aminoisobutyric acid transport in an obligately alkalophilic bacterium. Journal of Biological Chemistry 253, 708-715.

Guffanti, A. A., Blanco, R. \& Krulwich, T. A. (1979a). A requirement for ATP for $\beta$-galactoside transport by Bacillus alcalophilus. Journal of Biological Chemistry 254, 1033-1037.

Guffanti, A. A., Monti, L., Blanco, R., Ozick, D. \& KRULWICH, T. A. $(1979 b)$. $\beta$-Galactoside transport in an alkaline-tolerant strain of Bacillus circulans. Journal of General Microbiology 112, 161-169. 
Harold, F. M. \& Papineau, D. (1972). Cation transport and electrogenesis by Streptococcus faecalis. II. Proton and sodium extrusion. Journal of Membrane Biology 8, 45-62.

Hegeman, G. D. (1966). Synthesis of the enzymes of the mandelate pathway by Pseudomonas putida. I. Synthesis of enzymes by the wild type. Journal of Bacteriology 91, 1140-1154.

LANYI, J. K. \& MACDoNALD, R. E. (1976). Existence of electrogenic hydrogen ion/sodium ion antiport in Halobacterium halobium cell envelope vesicles. Biochemistry 15, 4608-4614.

Mandel, K. G. \& Krulwich, T. A. (1979). Monovalent cation-proton antiports in membrane vesicles of Bacillus alcalophilus. Abstracts of XIth International Congress of Biochemistry, Toronto, Canada, p. 449.

MitCHELl, P. (1961). Coupling of phosphorylation to electron and hydrogen transfer by a chemiosmotic type of mechanism. Nature, London 191, 141148.

Niven, D. F. \& Macleod, R. A. (1978). Sodium ionproton antiport in a marine bacterium. Journal of Bacteriology 134, 737-743.

Padan, E., Zilberstein, D. \& RotrenberG, H. (1976). The proton electrochemical gradient in Escherichia coli cells. European Journal of Biochemistry 63, 533-541.

Pillay, D. T. N. \& MEHDI, R. (1970). Separation of amino acids by thin-layer chromatography. Journal of Chromatography 47, 119-123.

Ramos, S. \& KaBACK, H. R. (1977). The electrochemical proton gradient in Escherichia coli membrane vesicles. Biochemistry 16, 848-854.
RAMOs, S., Schuldiner, S. \& KabaCK, H. R. (1976). The electrical gradient of protons and its relationship to active transport in Escherichia coli membrane vesicles. Proceedings of the National Academy of Sciences of the United States of America 73, 1892-1896.

Schulachev, V. P. (1978). Membrane linked energy buffering as the biological function of $\mathrm{Na}^{+} / \mathrm{K}^{+}$ gradient. FEBS Letters 87, 171-179.

SchUldiner, S. \& FishKES, H. (1978). Sodiumproton antiport in isolated membrane vesicles of Escherichia coli. Biochemistry 17, 706-711.

Schuldiner, S. \& KaBACK, H. R. (1975). Membrane potential and active transport in membrane vesicles from Escherichia coli. Biochemistry 14, 5451-5461.

Stanley, P. E. \& Williams, S. G. (1969). Use of the liquid scintillation spectrometer for determining adenosine triphosphate by the luciferase enzyme. Analytical Biochemistry 29, 381-392.

STock, J. B., Rauch, B. \& Roseman, S. (1977). Periplasmic space in Salmonella typhimurium and Escherichia coli. Journal of Biological Chemistry 252, 7850-7861.

Thompson, J. (1976). Characteristics and energy requirements of an $\alpha$-aminoisobutyric acid transport system in Streptococcus lactis. Journal of Bacteriology 127, 719-730.

Wolfson, P. J. \& Krulwich, T. A. (1972). Inhibition of isocitrate lyase: the basis for inhibition of growth of two Arthrobacter species by pyruvate. Journal of Bacteriology 112, 356-364. 